\title{
Fibrin Degradation Products in Sera of Women with Normal Menstruation and Menorrhagia
}

\author{
HIMANSU K. BASU, ${ }^{*}$ F.R.C.S.ED., M.R.C.o.G.
}

British Medical fournal, 1970, 1, 74-75

\begin{abstract}
Summary: Serum concentrations of fibrin degradation $\checkmark$ products were found to be higher during menstruation than in the intermenstrual phase. Higher concentrations were present in cases of menorrhagia as compared with healthy women and women with various gynaecological disorders but with normal menstrual function. Higher serum concentrations of fibrin degradation products in cases of menorrhagia may indicate increased local fibrinolytic activity in the uterus.
\end{abstract}

\section{Introduction}

It has been suggested that a state of increased local fibrinolytic activity in the uterus may be a possible cause of functional menorrhagia (Nilsson and Björkman, 1965). The diagnosis of local fibrinolysis, however, has been presumptive, being based on the finding of diminished menstrual loss following therapeutic administration of inhibitors of fibrinolysis (Nilsson and Rybo, 1965; Vermylen et al., 1968). A recent approach to the study of in-vivo fibrinolytic activity has been the measurement of the concentration of fibrin degradation products (F.D.P.) in the systemic blood (Das et al., 1967). It is known that the uterus is a site of fibrinolytic activity and that F.D.P. are released into the uterine venous blood both in the nonpregnant state and during pregnancy (Mackay et al., 1967; Basu and Jeffcoate, 1969; Prentice et al., 1969). Release of large quantities of F.D.P. into the uterine venous blood can lead to increased concentration of F.D.P. in the peripheral venous blood. This communication describes the results of assays of F.D.P. in the sera in women with normal menstruation and menorrhagia.

\section{Materials and Methods}

Assays were performed on blood obtained from the following groups of women.

Group 1. Healthy Women.-A total of 149 specimens of blood were obtained from 42 apparently healthy women who had regular menstrual cycles with average loss. Their ages varied from 17 to 43 (average 26) years and parity ranged from 0 to 5 (average 1). From each subject blood was obtained at least twice during a menstrual cycle-once during the menstrual period and again in the intermenstrual phase. The number of cycles during which blood was obtained from each woman ranged from one to three.

Group 2. Gynaecological Patients with Normal Menstrual Function (controls).- Seventy-eight specimens of blood were obtained from 76 patients suffering from various gynaecological conditions such as fibroid, prolapse, cervical erosion, etc. The menstrual cycles in these women were regular. Their ages ranged from 19 to 50 (average 33) years and parity from 0 to 7 (average 2).

Group 3. Women with Menorrhagia.-Seventy-five specimens of blood were obtained from 70 women suffering from menorrhagia. Their ages varied from 18 to 53 (average 37 ) years and parity ranged from 0 to 8 (average 3 ). Menorrhagia * Research Fellow, Department of Obstetrics and Gynaecology, University
of Liverpool. was diagnosed when excessive menstrual loss necessitated gynaecological investigations such as a diagnostic curettage. Obvious organic causes were present in 31 cases.

With the subject at rest $5 \mathrm{ml}$. of blood was obtained from an antecubital vein with minimum venous occlusion and collected in 500 kallikrein inactivating units (K.I.U.) of aprotinin (Trasylol). The serum was separated after incubating the clotted blood at $37^{\circ} \mathrm{C}$. for one hour, and one-tenth of its volume of thrombin solution (100 units $/ \mathrm{ml}$.) was added to remove residual fibrinogen.

The serum was adsorbed overnight with $1 / 5$ volume of packed formolized sheep red blood cells at $4^{\circ} \mathrm{C}$. The concentrations of F.D.P. were determined by the haemagglutination inhibition method (Merskey et al., 1966), the microtitre system (Cooke Engineering Co.) being used. A solution of purified human fibrinogen (Kabi Pharmaceuticals Ltd.) at an approximate concentration of $10 \mu \mathrm{g} . / \mathrm{ml}$. and a solution of pooled human plasma ( 1 in 100 in citrate phosphate buffer and adsorbed with sheep red blood cells) were used as standards in each batch of assays. The concentrations of clottable protein in the standard solutions were determined by the method of Ratnoff and Menzie (1951). The sensitivity of the assay method was $0.5-0.6 \mu \mathrm{g} . / \mathrm{ml}$.

\section{Results}

In all three groups there were only slight changes in the mean levels of F.D.P. from week to week during the intermenstrual phase, but during the menstrual period the levels were higher (Table I). Women with menorrhagia appeared to

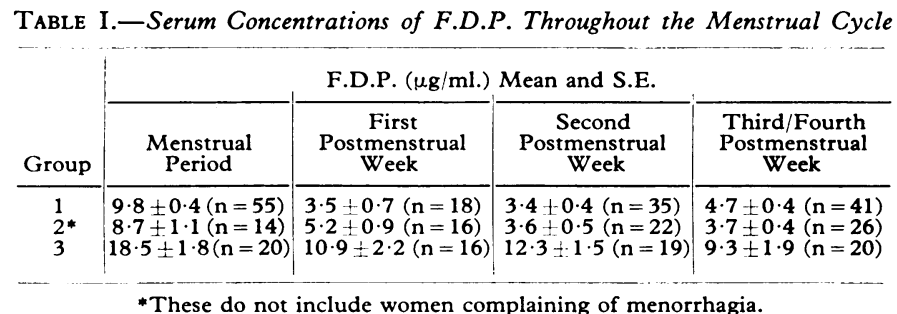

*These do not include women complaining of menorrhagia.

TABLE II.-Serum F.D.P. in Women with Normal Menstrual Loss

\begin{tabular}{|c|c|c|c|}
\hline & \multicolumn{2}{|c|}{$\begin{array}{c}\text { Serum F.D.P. }(\mu \mathrm{g} / \mathrm{ml} .) \text { Mean and S.E. } \\
\text { Samples from Women aged } 35 \\
\text { and Under }\end{array}$} & \multirow[b]{2}{*}{$\begin{array}{l}\text { Degree of } \\
\text { Significance }\end{array}$} \\
\hline & $\begin{array}{l}\text { Menstrual } \\
\text { Phase }\end{array}$ & $\begin{array}{l}\text { Intermenstrual } \\
\text { Phase }\end{array}$ & \\
\hline $\begin{array}{l}\text { Group } 1 \\
\text { Group 2* }\end{array}$ & $\begin{array}{l:l}10 \cdot 2 & 0.5(n=47) \\
8 \cdot 8 & 1 \cdot 3(n=10)\end{array}$ & $\begin{array}{l}4 \cdot 10 \cdot 3(n=79) \\
4 \cdot 4 \pm 0.4(n=38)\end{array}$ & $\begin{array}{l}<0.001 \\
<0.01\end{array}$ \\
\hline Degree of Significance & $P>0.05$ & $P>0.05$ & - \\
\hline
\end{tabular}

\begin{tabular}{|c|c|c|c|}
\hline \multirow[b]{2}{*}{$\begin{array}{l}\text { Group 1 } \\
\text { Group 2* }\end{array}$} & \multicolumn{2}{|c|}{$\begin{array}{c}\text { Samples from Women aged } 36 \\
\text { and Over }\end{array}$} & \multirow[b]{2}{*}{$\begin{array}{l}P<0.01 \\
P<0.01 \\
\end{array}$} \\
\hline & $\begin{array}{l}7 \cdot 7 \pm 0 \cdot 9(n=8) \\
8 \cdot 2 \pm 2 \cdot 3(n=4)\end{array}$ & $\begin{array}{l}3.50 .7(n=15) \\
3.5 \pm 0.5(n=26)\end{array}$ & \\
\hline Degree of Significance & $P>0.05$ & $P>0.05$ & - \\
\hline
\end{tabular}


have higher mean levels of F.D.P. than did the other two groups of women. There was, however, considerable difference as regards the distribution of age and parity between the three groups of women. The serum concentration of F.D.P. did not appear to vary appreciably with parity, or with age for ages up to 35 years, but for higher ages the levels were appreciably lower than those in the younger women.

A consideration of the results on blood obtained from healthy women (group 1) and from gynaecological patients without disturbed menstrual function (group 2) showed no appreciable difference between the groups (Table II). The results on blood obtained from these two groups of women and those from women with menorrhagia are compared in

TABLE III.-Comparison of Serum F.D.P. in Women with Menorrhagia and in Those with Normal Menstrual Loss

\begin{tabular}{|c|c|c|c|}
\hline & \multicolumn{2}{|c|}{$\begin{array}{c}\text { Serum F.D.P. ( } \mu \mathrm{g} . / \mathrm{ml} .) \text { Mean and S.E. } \\
\text { Samples from Women aged } 35 \\
\text { and Under }\end{array}$} & \multirow[b]{2}{*}{$\begin{array}{l}\text { Degree of } \\
\text { Significance }\end{array}$} \\
\hline & $\begin{array}{l}\text { Menstrual } \\
\text { Phase }\end{array}$ & $\begin{array}{c}\text { Intermenstrual } \\
\text { Phase }\end{array}$ & \\
\hline $\begin{array}{l}\text { Groups } 1 \text { and } 2 \\
\text { Group } 3\end{array}$ & $\begin{array}{c}9 \cdot 9 \pm 0 \cdot 4(n=57) \\
24 \cdot 0 \pm 0 \cdot 7(n=11)\end{array}$ & $\begin{array}{l}4 \cdot 2 \pm 0 \cdot 2(n=117) \\
13 \cdot 7 \pm 1 \cdot 5(n=23)\end{array}$ & $\begin{array}{l}\mathrm{P}<0.001 \\
\mathrm{P}<0.001\end{array}$ \\
\hline Degree of Significance & $P<0.001$ & $P<0.001$ & - \\
\hline
\end{tabular}

\begin{tabular}{|c|c|c|c|}
\hline \multirow[b]{2}{*}{$\begin{array}{l}\text { Groups } 1 \text { and } 2 \\
\text { Group } 3\end{array}$} & \multicolumn{2}{|c|}{$\begin{array}{l}\text { Samples from Women aged } 36 \\
\text { and Over }\end{array}$} & \multirow[b]{2}{*}{$\begin{array}{l}<0.001 \\
>0.05\end{array}$} \\
\hline & $\begin{array}{l}7 \cdot 9 \pm 0.9(n=12) \\
11.9 \pm 2 \cdot 5(n=9)\end{array}$ & $\begin{array}{l}3.5 \pm 0.4(n=41) \\
8 \cdot 7 \pm 1 \cdot 4(n=32)\end{array}$ & \\
\hline Degree of Significance & $\mathrm{P}>0.05$ & $<\mathrm{P} 0.001$ & - \\
\hline
\end{tabular}

Table III. Women with functional menorrhagia had higher mean levels of F.D.P. than did those with menorrhagia due to organic causes $(\mathrm{P}>0.05)$.

\section{Discussion}

The results of this study indicate that, generally speaking, the concentrations of F.D.P. in the sera of women are higher during the menstrual period than in the intermenstrual phase.

This is in contrast with the opinion expressed by Das et al. (1967), who found no significant alterations in the serum concentration of F.D.P. in four healthy women studied throughout the menstrual cycle.

The demonstration of an anticoagulant effect (which could be neutralized by protamine sulphate) in the blood of menstruating women by Rumbolz et al., in 1952, when the existence of F.D.P. was unknown, is of interest. They demonstrated that the concentration of the anticoagulant in the blood was higher during menstruation than in the intermenstrual phase and was also higher in women who had had abnormal uterine haemorrhage (including menorrhagia) than in women with normal menstrual loss. It is known that F.D.P. have anticoagulant properties which can be neutralized by protamine sulphate (Vreeken et al., 1966).

If it is assumed that increased concentrations of F.D.P. in the blood during menstruation result from excessive fibrinolytic activity, the latter is likely to be limited to the circulation of one or more organs as a local phenomenon. This is because fibrinolytic activity of the systemic blood is not increased during menstruation (Beller et al., 1964). Mackay et al. (1967) produced evidence to suggest that F.D.P. may be released into the uterine venous system (and indirectly into the systemic blood). They thought that this may be a function of the vascularity of the organ, presumably because vascular endothelium is a source of plasminogen activator (Kwaan and Astrup, 1967). Increased vascularity of the uterus during menstruation may therefore lead to the release of a large quantity of F.D.P. from the uterus into the systemic circulation.

Other observations suggest that fibrinolytic activity in the uterus may be increased during menstruation. Fibrinolytic activity of endometrial homogenates in saline was found to be significantly higher during menstruation than in the premenstrual phase (Rybo, 1966). The concentrations of plasminogen activator in the endometrium is known to undergo cyclical variations, the maximum concentration being reached during the premenstrual period (Rybo, 1966). It is possible that the premenstrual period represents a storage phase, and that during menstruation a large amount of activator is released into the uterine circulation. This results in a lower concentration of activator in the endometrium during the regenerative phase. Thus it is reasonable to assume that alterations in the serum concentration of F.D.P. throughout the menstrual cycle may be due, at least in part, to alterations in the local fibrinolytic activity in the uterus. Increased levels of F.D.P. during menstruation may also be linked with intravascular and extravascular deposits of fibrin present in the menstrual endometrium (Salvatore, 1969). These deposits probably stimulate secondary fibrinolytic activity and release a large quantity of F.D.P.

The exact relation between menorrhagia and increased local fibrinolytic activity in the uterus is not certain. Though local fibrinolytic activity is considered to be a cause of menorrhagia (Nilsson and Björkman, 1965), it is possible that widespread endometrial necrosis and hypoxia associated with increased menstrual bleeding may result in increased local fibrinolytic activity (Clarke and Cliffton, 1962). Alternatively, both menorrhagia and increased local fibrinolytic activity may originate from a common mechanism such as increased vascularity of the uterus or altered activity of steroid hormones. The results reported here emphasize the need for further studies in this field.

The project was financed by generous grants from the Wellcome Trust and the Research Committee of the United Liverpool Hospitals. I am indebted to Professor T. N. A. Jeffcoate and Dr. B. M. Hibbard for constant encouragement and guidance, to $\mathrm{Mr}$. G. F. Williamson for technical assistance, and to the consultant gynaecological staff at the Liverpool Royal Infirmary and Mill Road Maternity Hospital, Liverpool, for allowing me to study patients under their care. I am grateful to the medical and nursing staff of both hospitals and to the patients and volunteers who gave blood for the study. Materials were kindly supplied by F. B. A. Pharmaceuticals Ltd. Mr. R. H. Daw helped in the interpretation of the statistics.

\section{REFERENCES}

Basu, H. K., and Jeffcoate, T. N. A. (1969). American fournal of Obstetrics and Gynecology. In press.

Beller, F. K., Goebelsmann, V., Douglas, G. W., and Johnson, A. (1964) Obstetrics and Gynecology, 23, 12 .

Clarke, R. L., and Cliffton, E. E. (1962). American fournal of Medical Science, 244, 466.

Das, P. C., Allan, A. G. E., Woodfield, D. G., and Cash, J. D. (1967). British Medical fournal, $4,718$.

Kwaan, H. C., and Astrup, T. (1967). Thrombosis et Diathesis Haemorrhagica,

18, 296. fournal of Clinical Pathology, 20, 227.

Merskey, C., Kleiner, G. J., and Johnson, A. J. (1966). Blood, 28, 1.

Nilsson, I. M., and Björkman, S. E. (1965). Acta Medica Scandinavica, 177, 445.

Nilsson, L., and Rybo, G. (1965). Acta Obstetricia et Gynecologica Scandinavica, 44, 467

Prentice, C. R. M., McNicol, G. P., and Douglas, A. S. (1969). fournal of Clinical Pathology, 22, 367.

Ratnoff, O. D., and Menzie, C. (1951). Fournal of Laboratory and Clinical Medicine, 37, 316.

Rumbolz, W. L., Moon, C. F., and Novelli, J. C. (1952). American fournal of Obstetrics and Gynecology, 63, 1029.

Rybo, G. (1966). Acta Obstetricia et Gynecologica Scandinavica, 45, 429

Salvatore, C. A. (1969). American fournal of Obstetrics and Gynecology, 103, 537 .

Vermylen, J., Verhaegen-Declereq, M. L., Vêrstraete, M., and Fierens, F. (1968). Thrombosis et Diathesis Haemorrhagica, 20, 583.

Vreeken, J., Deggeller, K., Stoepmen-Van Dalen, E. A., Kleinherenbrink, M., and Van der Meer, J. (1966). In Coagulation Disorders in Obstetrics, edited by J. C. DeNeef and G. J. H. Den Ottolander, Amsterdam, Excerpta Medica, p.17. 